\title{
Once grand, now forgotten: what do we know about the superhigh-organic- sulphur Raša coal?
}

The Mining-Geology-Petroleum Engineering Bulletin UDC: 553.9

DOI: $10.17794 / \mathrm{rgn} .2016 .3 \cdot 3$

Review scientific paper

\author{
Gordana Medunić $^{1 *}$, Ankica Rađenović ${ }^{2}$, Mladen Bajramović ${ }^{3}$, Mirna Švec ${ }^{1}$, Matea Tomac \\ ${ }^{1}$ University of Zagreb, Faculty of Science, Department of Geology, Horvatovac 95, Zagreb, 10000, Croatia \\ ${ }^{2}$ University of Zagreb, Faculty of Metallurgy, Aleja narodnih heroja 3, Sisak, 44000, Croatia \\ ${ }^{3}$ Society 'Istrian coal mines Raša', Nikole Tesle 1, Raša, 52223, Croatia \\ *gmedunic@geol.pmf.hr
}

\begin{abstract}
The Istrian coal mines, located in the eastern part of the Istrian Peninsula (Northern Adriatic Sea, Croatia) had by far the most important and economically the most valuable deposits of the anthracite coal reserves in Croatia since the 18th century until the year 1999, when their excavation and use in the coal-fired power plant Plomin ceased. The coal is found within the Palaeocene Kozina limestone beds. Four coal basins, Karojba, Sveti Martin, Pićan, and the Labin basin, hosted seven coal mines, e.g. Tupljak, Potpićan, Kozljak, Štrmac, Raša, Ripenda, and Krapan. The coal has been generally known under the name of Raša coal. It is exceptional in world terms due to its high content of organic sulphur, which can be up to $14 \%$. Herewithin, this paper reviews Croatian scientific publications devoted to various aspects of Raša coal, along with the most important publications on either similar coals or relevant subjects worldwide. A brief introduction deals with the role of coal in electricity production, and the history of coal mining in Istria. The following chapter summarises current knowledge of the coal sulphur geochemistry, with several examples of high-sulphur coals from India and China. It is followed by the geological, geochemical, and physical characterisation of Raša coal. Since perturbations to ecosystems caused by coal combustion have been documented in numerous papers from a number of countries, Croatian studies carried out to determine the impact of Raša coal combustion on the local environment are also presented.
\end{abstract}

\section{Keywords}

Coal, mining, sulphur, Raša, Istria

\section{Introduction}

Human society unequivocally depends on energy, but the methods of its generation from an environmental point of view raise a lot of controversy (Adriano et al., 1980; Querol et al., 1992, 1995; Llorens et al., 2001; Xu et al., 2003; Tang et al., 2008; Vejahati et al., 2010; Csavina et al., 2012; Silva et al., 2012; Flues et al., 2013). Generally, two main power generation options exist, i.e. renewable sources (wind, sun, biomass, etc.), and depletable fossil fuels. The latter applies to crude oil, coal and gas, which account for more than 88\% (Judkins et al., 1993) or 84\% (Shafiee and Topal, 2009) of commercial energy sources, and their worldwide use is growing, particularly in the developing nations. Judkins et al. (1993) asked the followingprovocative question: 'Considering the environmental problems associated with the increasing use of fossil fuels, why are they so popular? The authors clearly elaborated that 'fossil fuels are so important because they are still relatively abundant, cheap, ubiquitous, and some forms (notably petroleum) are readily transportable'. Also, their optimistic message is directed towards the adoption of emission control technologies for reducing acidic deposition as well as greenhouse gases. Similarly, Shafiee and Topal (2009) affirm a great role of the huge reserves and the cheap price of coal in its potential as the most available fossil fuel in the future. This is not surprising taking into account the fact that coal accounts for $65 \%$ of the total world fossil fuel reserves, and its 
occurrence is broadly distributed around the world; hereby, it is responsible for nearly $40 \%$ of the world power generation. The authors also specify that 'nobody can predict exactly when supplies of fossil fuels will be exhausted'. According to their new formula (Shafiee and Topal, 2009) for calculating when fossil fuel reserves are likely to be depleted, if the world will consume fossil fuels at 2006 rates, the reserves of oil, coal and gas will last for 40, 200 and 70 years, respectively. Also, Thielemann et al. (2007) estimate that up to the year 2100 there will be no bottleneck in coal supplies on the whole planet. On the other hand, Abadie and Chamorro (2009) demonstrate that as 'coal-fired plants enjoy an initial advantage in terms of cheap fuel for generating electricity, an increase in the price of the emission allowances can significantly erode their profit margins'. Croatian scientists have also explored the electricity production issue regarding external costs (Božičević Vrhovčak et al., 2005) and Kyoto Protocol (Duić et al., 2005).

\section{Raša coal mining history}

Available historical material consisting of a number of historical documents, as well as the available written material (Vorano, 1997), confirms the fact that mining in the area of Labin began precisely in, what is now the municipality of Raša, the former mining center of Krapan (Figure 1).

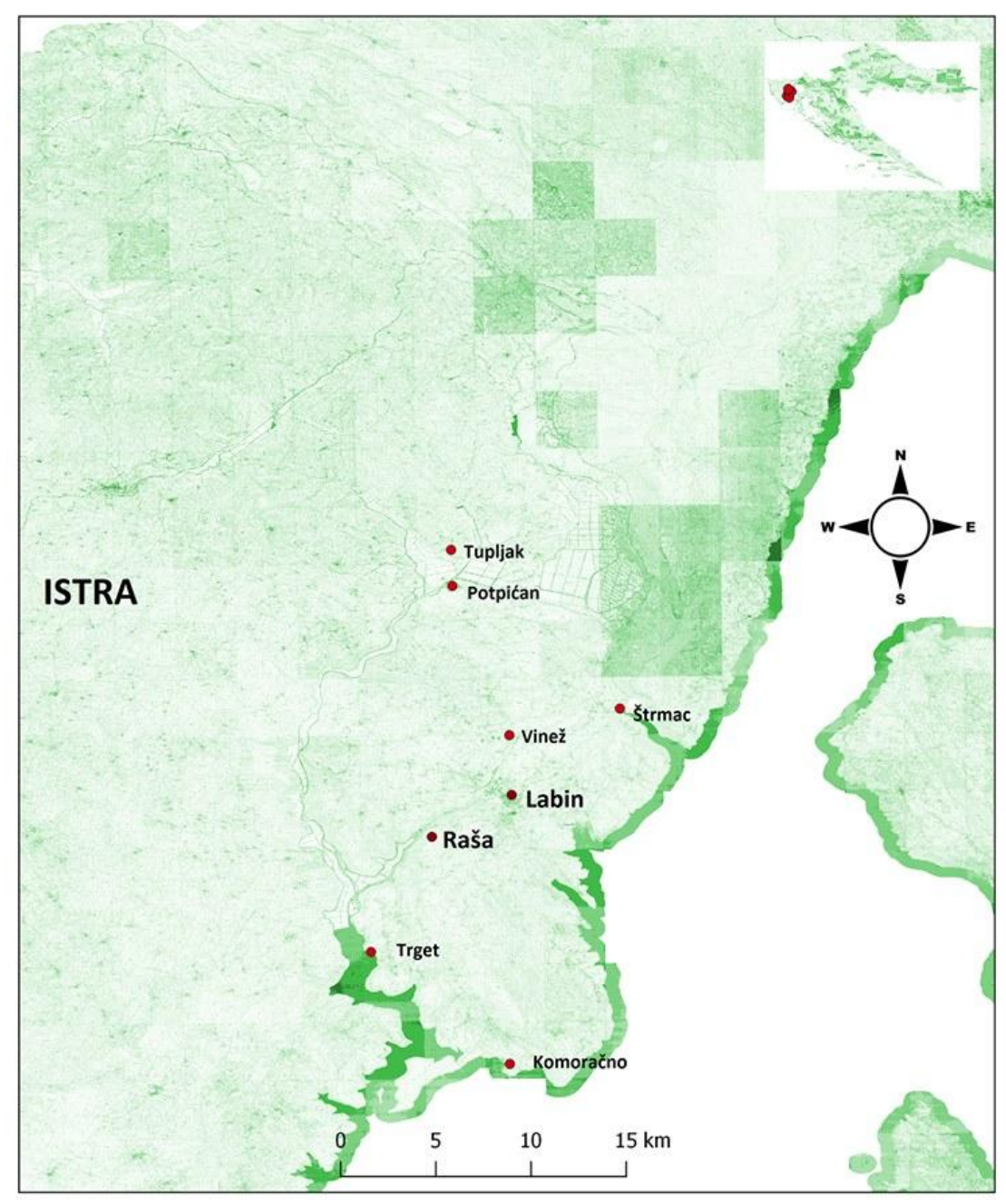

Figure 1. Geographic setting of the Labin and Raša coal mines 
It is an integral part of these municipalities, located a few hundred meters away from the mining settlement Raša, built during the so-called fascist era. Historical documents mention that the 15th century was the beginning of mining activities in this area. During the centuries of mining activities in this area, many empires, monarchies, regimes and states changed. Regarding miners, they were affected by various factors such as the change of government in the management of a mine, the development of mining as an industry, and unsafe and life-threatening working conditions.

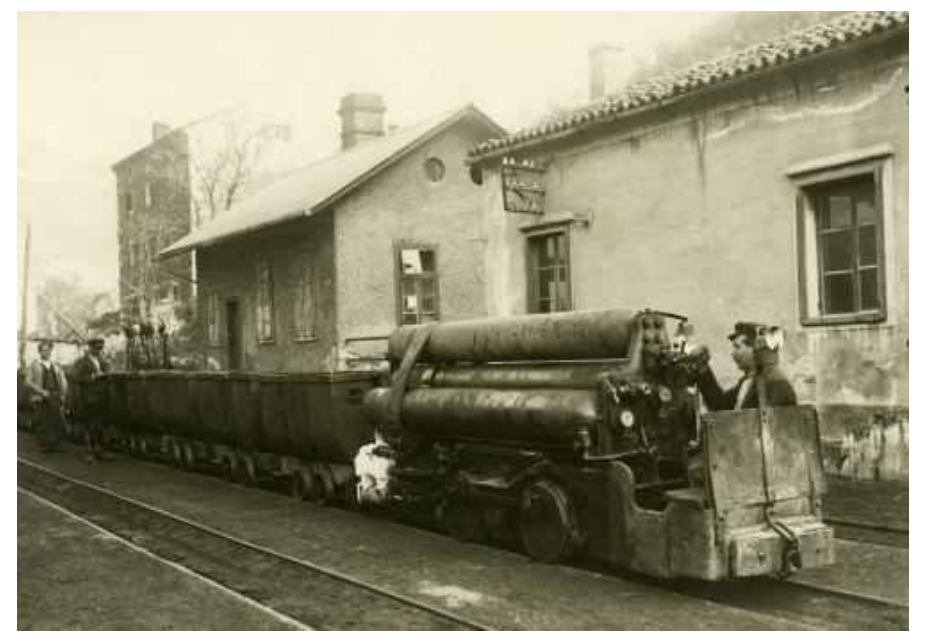

Figure 2. Krapan locomotive, $20^{\text {th }}$ century

Taken from URL: http://vmrii.com/hr/microsite/rudarstvo/

The beginning of mining in the area of today's Municipality of Raša in the town Krapan began in 1420 under Venetian rule. Namely, outcrops of tar-like coal were found, which were then used as a resin employed in the impregnation of the lower part of boats and flares. In the following years, there were several, mostly unsuccessful, attempts to find coal. Following the Industrial Revolution, coal gradually went through various developments, and that period was marked by the signing of the concession for the management of the Raša underground reserves. It is believed that the middle of the 18th century marked a turning point in the development of coal mines, because that is when hard coal was found due to intensive mining work (see Figure 2), and therefore mining became the necessary economic activity. In 1785, the continuous production of coal started, with further growth in the coming years and decades. The first serious contract was signed between the mine and the then Rijeka's sugar refinery, which created conditions for higher production. Rijeka's sugar refinery was the plant that looked for coal as the main energy source in the production activities. In the 18th century, Venetians were very interested in coal mines in the area of Labin, and the production rights were organised ten years prior to the fall of the famous Venetian Republic. That period was too short to generate economic benefits, but it certainly created the basis for further development and growth of production. 


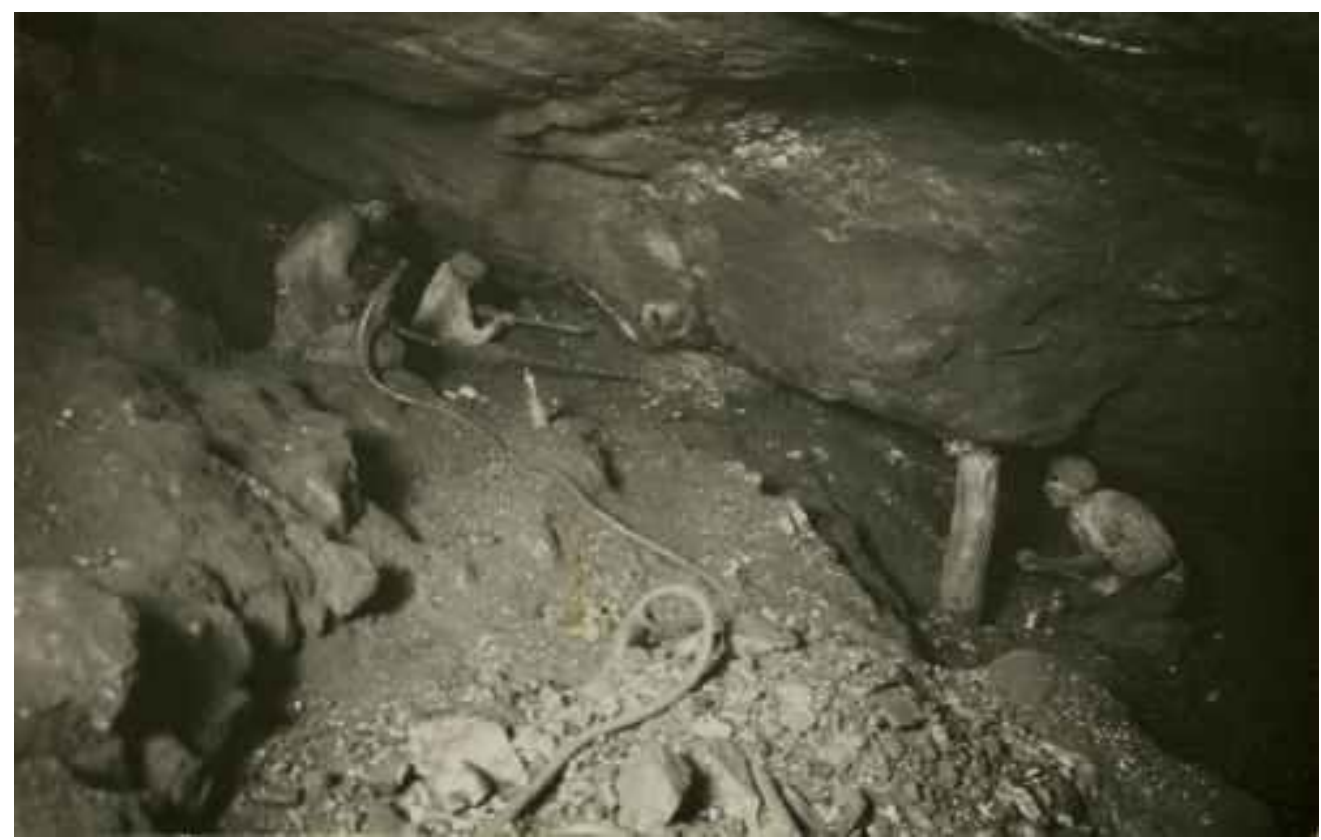

Figure 3. Miners working in the Raša coal mine, $2 \mathrm{o}^{\text {th }}$ century

Taken from URL: http://vmrii.com/hr/microsite/rudarstvo/

With the arrival of Napoleon, two very important decrees were signed; the first one was signed in 1807, which allowed the export of coal from Istria, and the rules regulating the sale of coal on the market, whilst the second one in 1808 regulated the mining industry as a profession. Regarding the constant and continuous production of coal in the area of today's Municipality of Raša, it should be mentioned that in the year 1830, systematic production started in Krapan. At the beginning of 1879 , production in the mine shaft Vinež began. The 1930s were a very important period in regard to mining in the area of Labin. Coal was in very high demand, and the demand for coal as an energy fuel engulfed the whole area of the then Europe.

In the second half of the 19th century, due to the rise of industrialization in the Austro-Hungarian economy, the demand for coal dramatically increased. A growing number of workers had been hired, along with the opening of new pits in the surrounding area. Thus there was a need for equipment in the process of mining, especially in the transportation sector and coal cleaning. The year 1881 was extremely important in the history of mining in this region because all the Labin mines merged into one production-technological unit, which resulted in an increase in production and the competitiveness of the Raša coal market.

At that time, the administration was aimed at the growing profits, and so miners were threatened from the standpoint of safety at work, but were also threatened by the security and stability of the coal seams. Wages were very low, and shifts were even twelve hours long and exhausting. The first mining riots and strikes were recorded in 1876 and 1878, due to resentment about low pay and poor working conditions. Given that salary payments were not raised in accordance with the agreement between the management and miners, miners immediately reacted and took action in the form of a strike in 1883. Following the first strike, a whole series of strikes ultimately evolved into the biggest 1921 strike in the region known as the Labin Republic. The First World War brought new troubles in mine operations because many miners went on the front line, and the decreased mine labor force affected the operation of the mine. The miners were strategically important as the coal mines were under the jurisdiction of the Austro-Hungarian army. Following the collapse of the Austro-Hungarian monarchy, under the Italian rule from 1918 until 1945, the company ARSA was established, which began with a large investment in the modernization and electrification of the mine. 


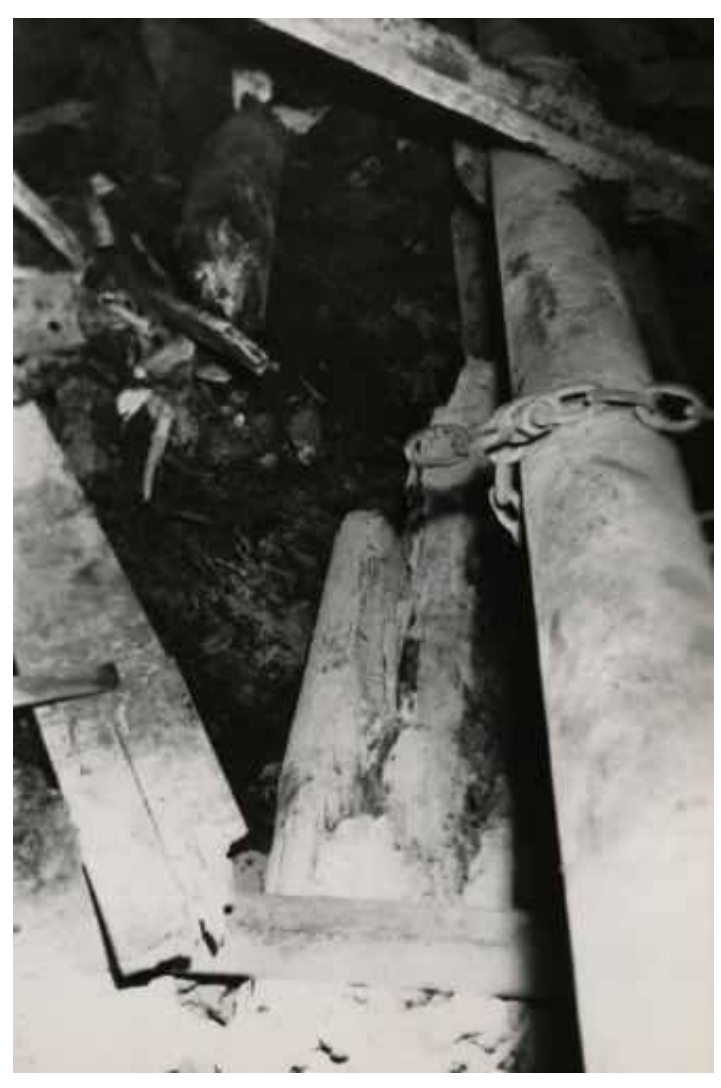

Figure 4. Collapse of roofing within the mine

Taken from URL: http://vmrii.com/hr/microsite/rudarstvo/

The period between 1936 and 1940was recorded as the most productive period in regard to production as well as the sale of coal, especially due to the opening of a new mine in Podlabin which was territorially part of the then Raša municipality. During the Second World War, the largest production was in the Raša mine (see Figure 4). Also, at the same time, the need for new accommodation facilities for the miners resulted in the construction of a new mining settlement in Raša (in 1936), which soon became the municipality.

World War II brought the very same troubles as those during the First World War. The growing economic crisis, inflation, and lack of manpower in the coal mine almost led to the collapse of the mine. Following the liberation of Istria in 1943 and the acquisition in Yugoslavia in 1945, a new organisation of work was founded in the newly founded Istrian coal mines Raša. The company Istrian coal mines Raša included a series of mines in the area of Labin as follows: Raša, Labin, Ripenda, Potpićan, Tupljak, etc., constituting the joint entity within the Raša coal basin.

The post-war years were marked by an evident shortage of staff. Mass emigration in the post-war years was also reflected in the number of miners in the coal basin. In those years, the government tried to solve this problem with the influx of population from the rural and underdeveloped areas of the former Yugoslavia to the Labin area. The result of this approach led to an increase in the number of workers, and also to the expansion of coal production. In spite of all the security measures, improper previous excavation and complex tectonic geological conditions resulted in numerous mining accidents (see Figure 3). The mining activity suffered from a significant crisis in the 1960s, and it had been gradually substituted with metal-processing industries, whilst coal production was halved. There was also an exceptionally low price of oil on the market, which led to a replacement of coal with oil due to high prices and environmental unacceptability. Due to the hopelessness of the situation and the accumulation of surplus coal, the mine management and the company Elektroprivreda opened a new coal-fired power plant in Plomin in 1971. This act saved the work force and the production, while contributing to the energy independence of the former state. (see Figure 5) During the 1970s, the gradual closure of the Raša coal basin occurred. The Raša coal mine was one of the first mines which ended its exploitation in 1966. Other coal mines had recorded increasing losses, and in 1987 the disappointed miners started the 33-day strike that finally led to the closure of the unprofitable mines Labin and Ripenda. Herewithin, 
the company Istrian coal mines Raša completely shut down, which was followed by the establishment of a new company called Istrian coal mines Tupljak. The coal mine Tupljak could not provide coal reserves that would be sufficient to the power plant Plomin. At that time, the Elektroprivreda company as the sole purchaser of coal proposed the closure of the mine, claiming that production was expensive, and the coal was environmentally unacceptable. Instead of the planned closure in 1993, it was decided to proceed with the excavation of prepared coal reserves, with no extra investments in new production and infrastructure. In 1999, the coal mine Tupljak was closedas the last coal pit in the Raša coal basin. Hereby, an almost six century long tradition of coal mining in this area finally ended (Vorano, 1997).

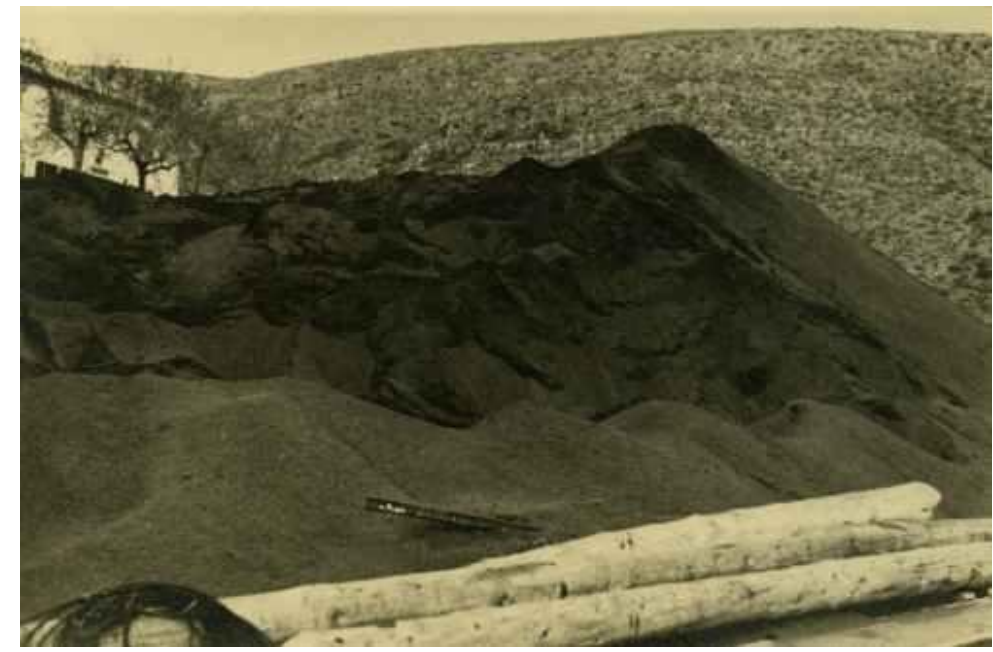

Figure 5. Piles of coal outside of the mine

Taken from URL: http://vmrii.com/hr/microsite/rudarstvo/

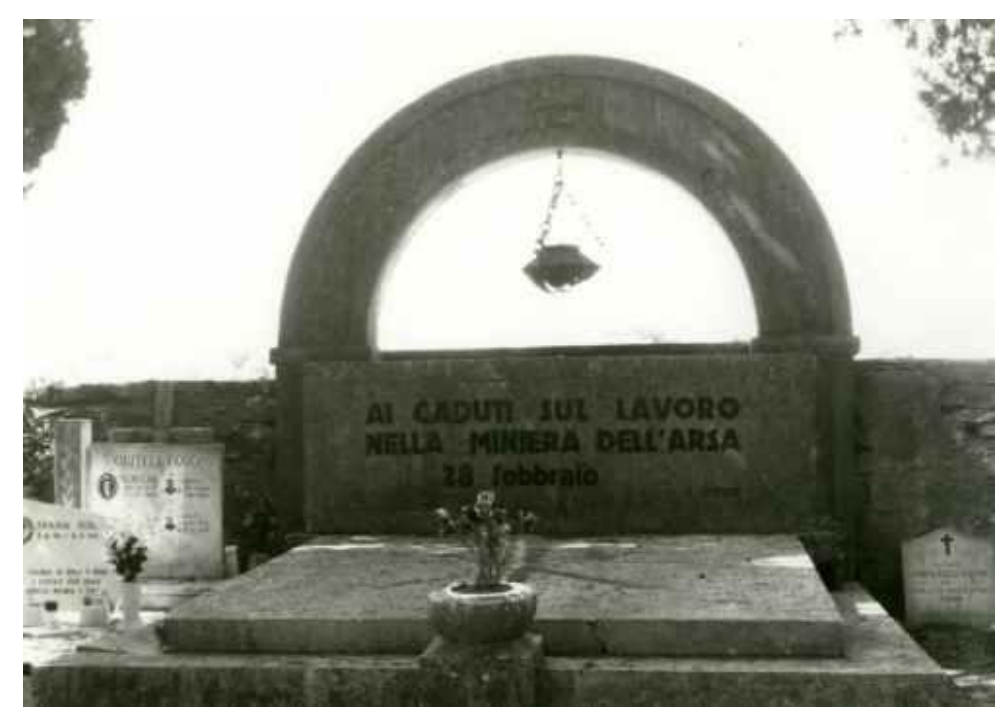

Figure 6. Monument placed to commemorate workers killed in various accidents

Taken from URL: http://vmrii.com/hr/microsite/rudarstvo/

\section{Sulphur cycling in the environment}

Sulphur in coal is derived from original plant material as well as from ambient fluids in the coal-forming depositional environment. Therefore, coal seams containing more than $3 \%$ of total S are commonly associated with marine strata (Casagrande, 1977; Chou, 1997). Sulphur, along with nitrogen and phosphorous, is an essential element in all living matter. Its characterisation, occurrence, ecotoxicology, and environmental fate have been studied extensively using 
various scientific approaches (Komarnisky et al., 2003; Jalilehvand, 2006; Kuklińska et al., 2013). It is ubiquitously present on Earth, existing in soils, sea water, and plants in organic forms as well as sulphates and sulphides, whereas in gaseous and solid states in the atmosphere (Badr and Probert, 1994; Brimblecombe, 2014). A considerable amount of research of sulphur emission processes, pathways, and budgets have been published so far (Glass, 1979; Manowitz and Lipfert, 1990; Querol et al., 1992; Badr and Probert, 1994; Dämmgen et al., 1998; Álvarez-Ayuso et al., 2006; Baruah and Khare, 2010; Smith et al., 2011). Herewithin, from the late 1960s onwards, the major role of $\mathrm{SO}_{2}$ in atmospheric pollution and the occurrence of acid rain has been widely recognised by an increasing number of researchers (Oden, 1976; Schindler, 1988; Galloway, 1995; Fowler et al., 2007). Namely, $\mathrm{SO}_{2}$ has been emitted whenever fuels containing sulphur, like coal, coke, and oil, are burnt. Its main anthropogenic emission sources are coalfired power stations, central-heating plants, and industrial furnaces in the iron and steel industry (Dunham et al., 1975; Koptsik and Alewell, 2007). Its deleterious effects on the ecosphere (Elsaesser, 1981) have spurred the increasingly stringent air quality regulations since the late 1970s onwards (WHO, 1982; U.S. EPA, 1990; EMEP/EEA, 2013). Moreover, the medical studies (Rall, 1974; Thibodeau et al., 1980; Amdur et al., 1986; Nemery et al., 2001; Mohorović, 2003, 2004; Kampa and Castanas, 2008) have clearly demonstrated the adverse effects of $\mathrm{SO}_{2}$ and a number of other air pollutants on human health. Briefly, Kampa and Castanas (2008) summarise them as follows: minor upper respiratory irritation to chronic respiratory and heart disease, lung cancer, acute respiratory infections in children and chronic bronchitis in adults, aggravating pre-existing heart and lung disease, or asthmatic attacks. Coal combustion processes in power plants also release ash, i.e. particulate matter enriched in metals and PAHs, which is hazardous to human health, and which has been repeatedly demonstrated by numerous environmental scientists (Cuddihy, 1983; Querol et al., 1996; Markandya and Wilkinson, 2007; McConnell and Edwards, 2008; Masto et al., 2011; Banerjee et al., 2015; Kumar et al., 2015; Laumbach et al., 2015; Martins et al., 2015). Also, active and historical mining activities have adverse effects on ecosystems (Larson et al., 2015; Chaput et al., 2014). Herewithin, it can be said that the fate of chemical releases from coal mining and coal-fired power plants should be thoroughly investigated and monitored so as not to harm life forms as well as buildings.

\section{Sulphur in coal}

Coal is undoubtedly the most complex geological material, being composed of the following components: organic matter $(\mathrm{C})$, water, oil $(\mathrm{CH})$, methane gas $\left(\mathrm{CH}_{4}\right)$, and virtually all the elements in the periodic table, sulphur in particular, together with a wide variety of minerals (Querol et al., 1995; Rađenović, 2006). For an excellent summary of the status of knowledge regarding the geochemistry of coal with a comprehensive list of references published until the late 1950s readers should consult Breger (1958). Also, papers published during the 1970s and 1980s properly addressed the complex problem of electricity generated by high-sulphur coal (Dunham et al., 1975; Manowitz and Lipfert, 1990), and the geochemical significance of sulphur species in high organic sulphur coal and the geosphere in general (Boudou et al., 1987).

Coal is a combustible, sedimentary rock formed from vegetation that has been consolidated between rock strata for millions of years (Speight, 2005). The initial reactions in the coalification process involve the microbial degradation of plant residues, either aerobically or anaerobically, into humins and peat. Increased pressure and temperature alter the physical and chemical characteristics of the resulting sediment, which is metamorphosed into coal. Due to the heterogeneity of plant tissue and varying geochemical conditions, the structure of coal will differ between coal seams (Kirby et al., 2010). Coal is mainly composed of organic carbonaceous matter, noted as macerals and inorganic minerals in various proportions. Depending on the source material and the conditions of its transformation in the peat stage of coal formation, the main maceral groups are: the vitrinite or gelinite, the exinite or liptinite group, and the inertinite. The maceral that fall in to the vitrinite group are derived from the humification of woody tissues and can either possess remnant cell structures or be structureless. The structureless maceral could have resulted due to the degradation process that takes place during coal diagenesis. Chemically it is composed of natural polymers, cellulose and lignin. Vitrinite contains more oxygen than the other macerals (Speight, 2013).

The members of the liptinite group are considered to originate from the resinous and waxy material of plants, including resins, cuticles, spores, pollen exines, and algal remains. They tend to retain their original plant form, i.e. they resemble plant fossils, and are characterised by high reactivity and volatility, and are more aliphatic. The members of this maceral group can be distinguished from the members of the vitrinite group by a higher hydrogen and lower oxygen content of all coal macerals. The members of the inertinite group are considered to be the equivalent of charcoal and degraded plant material, originating from plant material, usually woody tissues, plant degradation products, or fungal remains. 
Inertinite macerals are characterised by high reflectance as well as a distinct cell texture, and are highly oxidised in nature with a high inherent carbon content that resulted from thermal or biological oxidation (Speight, 2013).

Although the sulphur content in coals varies considerably, its total levels most commonly range from $0.5 \%$ to $5 \%$ (Chou, 1997, 2012; Rađenović, 2004). Generally, sulphur in coal occurs in pyritic, sulphate and organic forms. According to Chou (1997), the variation of sulphur in coal is controlled by geological conditions. Hereby, sulphur in plant material is the principle source of $\mathrm{S}$ in low-sulphur coals, whereas in medium- to high-sulphur coals, most of the $\mathrm{S}$ is derived from seawater sulphate. Also, sulphur in coals is an important parameter in the evaluation of coal resources (Chou, 2012).

Sulphur is the most abundant heteroatom in coals. The sulphur content and forms vary considerably with location and coal rank. Sulphur in coal appears in both organic (sulphur bonded to the hydrocarbon matrix) and in inorganic (metal sulphides, disulfides and sulphates) forms, and in the form of elemental sulphur (Kasrai et al., 1996). Elemental sulphur is not present in pristine coal, but is derived primarily from the oxidation of pyrite. It is generally present in relatively small amounts even in oxidised coals. Iron disulfide, $\mathrm{FeS}_{2}$, appears in two crystalline forms, pyrite (cubic) and marcasite (rhombic). Pyrite is the predominant sulfide mineral in coal. Other sulfide minerals include marcasite, pyrrhotite, sphalerite, galena, and chalcopyrite, as well as rare occurrences of getchellite and alabandite. The sulphate sulphur appears mainly in the form of calcium and iron sulphates. The organic sulphur compounds in coals may be classified into three categories: 1) thiols, 2) sulfides and disulfides, and 3) thiophene and its derivatives. The sulphur-containing aromatic compounds (benzothiophene, dibenzothiophene, and benzonaphthothiophene) were found in bituminous coal and anthracite, but not in lignite. Herewithin, the abundance of various types of organic sulphur compounds in coal may be related to the rank of coal (Rađenović, 2004; Chou, 2012). In contrast to inorganic sulphur, such as pyrite which can be isolated by physical methods, organic sulphur is part of the coal structure, and therefore it cannot be removed by physical methods. Organic sulphur in coal is traditionally calculated as the difference between the total sulphur and the sum of pyritic plus sulphate sulphur (Attar, 1978).

High-sulphur coals from the northeastern part of India were studied by a number of researchers. Papers by Mukherjee and Srivastava (2005), Dowarah et al. (2009), and Saikia et al. (2015) reported sulphur values in northeast Indian coals up to $4 \%, 12 \%$ and $4 \%$, respectively. Relevant Chinese studies report coal S values up to $8 \%$ (Guijian et al., 2001), $4 \%$ (Dai et al., 2002), and 11\% (Dai et al., 2008).

\section{I. Sulphur in Raša coal}

Superhigh-organic-sulphur (SHOS) coal is a special class of coal, characterised by remarkably elevated values of S, usually in the range of 4-11\% (Chou, 1997). The author compared organic S in Chinese SHOS coals, Guidin (7.719.18\%), and Yanshan (10.30\%), with Croatian SHOS coal from the Istrian Peninsula, i.e. Raša coal (10.52\%). White et al. (1990) reported that the Upper Palaeocene bituminous Raša coal was exceptional due to its high sulphur content, most of which was in organic form. Calcite and dolomite were reported as the major mineral phases, and the total sulphur on an as-received basis was $10.77 \%$ wt, including $0.02 \%$ sulphate, $0.3-0.63 \%$ pyrite, and $10.45 \%$ organic sulphur. Sinninghe Damsté et al. (1999) also found that the Raša coal had an unusually high amount of sulphur (11.79 $\mathrm{wt} \%)$, dominated by the anomalously high level of organic sulphur (11.44 wt\%).

Organic sulphur compounds formed during an early stage of the coalification process (humification) when plant debris is decomposed by bacterial activity to premaceral humic substances. After studying the maceral content, Hamrla (1960) concluded that the Raša coals were formed under completely anaerobic conditions.

The high organic sulfur content is a characteristic of marine-influenced bituminous coals. Raša coal appears to have been formed in a high-pH marine environment where bacteria thrived. This hypothesis (White et al, 1990) is supported by the presence of substantial amounts of both calcite and dolomite in Raša coal. The calcium- and magnesium-rich environment where Raša coal formed is expected to have been alkaline. The alkaline marine environment, having relatively high concentrations of alkaline earth ions, fostered bacterial growth in which products of bacterial action contributed to coal formation and sulphur fixation. This scenario fits well with the description provided by Hamrla (1960) concerning the environmental conditions that existed on the Istrian Peninsula during coalification. The high sulphur content of Raša coal suggests a source of sulphur other than that originally in the plants, which became incorporated in the vegetable debris that formed the coal. Plants do not typically contain enough sulphur to account for the very high values found in Raša coal. The sulphur in Raša coal is present as a result of the bacterial reduction of 
marine sulfate and subsequent incorporation of the reduced sulfur into the organic matrix. The low pyrite content of Raša coal is consistent with the minimal input of terrestrial iron by fresh water. An alkaline marine environment high in $\mathrm{H}_{2} \mathrm{~S}$ and HS- is favourable for the incorporation of sulphur into organic matter; HS- is an aggressive nucleophile. Elemental sulphur reacts with hydrocarbons to form organosulfur compounds, including thiophens at mild temperatures (White et al, 1988). Polysulphides react with conjugated ene carbonyls at room temperature to form thiophenes and other sulfur heterocycles (Lalonde et al, 1987).

Since the major biopolymers of terrestrial higher plants are lignin and cellulose, coals generally have a high content of oxygen. The very low amount of oxygen in Raša coal is very unusual for a coal. Therefore, there is no evidence to indicate that the organic matter is predominantly derived from terrestrial higher plants, indicating that Raša coal is certainly not a typical coal (Sinninghe Damste'et al, 1999).

\section{Geology of the Raša coal mines}

During the Late Carboniferous, up until the Early Triassic, the Adriatic region was located in northern Gondwana, on an epeiric platform (Vlahović et al, 2005). In the Early Triassic, a large shelf fragment was separated from Gondwana through rifting processes, forming the Adria microplate. Shallow-water shelf carbonates were deposited. Early Jurassic (Toarcian), however, was the period of differentiation of the Adriatic microplate as a result of extension. Few smaller platform areas were formed, separated by deep-sea basins. This is when the Adriatic Carbonate Platform was formed as well. All throughout Jurassic and Cretaceous periods, these platforms moved towards the Laurasia continent. This created the perfect platform for the sedimentation of thick carbonate layers, up to nine thousand meters thick. Vlahović et al (2005.) suggest that the thick carbonate deposits were deposited during the "pre-platform" phase (Late Carboniferous to Early Jurassic) along with the development of the Adriatic Carbonate Platform (Early Jurassic to Late Cretaceous). The Adriatic Carbonate Platform was significantly nearing Laurasia during the Upper Cretaceous (Cenomanian), which caused further differentiation and disintegration of the platform. By the end of the Cretaceous, most of the platform was uplifted, only some small areas continued the shallow-water sedimentation during the Paleogene as well. As the now emerged platform neared the Laurasia shore, subduction processes continued, causing the platform to gradually sink and be covered with water again (Eocene transgression). As a result, shallow-water sedimentation was re-established. There were also local deepenings, in which sediments fell from nearby slopes, thus depositing flysch sediments. As the subduction progressed, in the Eocene the platform structures of the former Adriatic Carbonate Platform collided with Eurasia, which is the part of the continent remaining in this area after Laurasia broke apart. This collision meant the karst Dinarides could finally be formed. Through erosion during the Eocene, Oligocene and Miocene, clastic carbonate sediments (molasses) were deposited. This extensive and detailed research and information enabled Vlahović et al (2005) to identify four megasequences based especially on the aforementioned two key phases: Early Jurassic (Toarcian) extension or formation of the Adriatic Carbonate Platform and Late Cretaceous disintegration of the Adriatic Carbonate Platform. The megasequences are: pre-platform Upper Carboniferous to Lower Jurassic, Lower Jurassic to Upper Cretaceous megasequence corresponding to the Adriatic Carbonate Platform, a postplatform Paleogene and Neogene megasequence and a Pliocene to Holocene megasequence. Within these megasequences, Vlahović et al (2005) defined six formations, including the post-platform Raša Formation, which belongs to the third megasequence. During the Late Cretaceous period, the north-eastern part of the Adriatic Carbonate Platform, where the Raša coal mines are situated, was uplifted. Transgression began in the Paleogene, and it marked the beginning of the deposition of various foraminiferal limestones. Water covered what is today our coast, islands and offshore, creating a shallow platform, slope and basinal settings. These limestones contain many specimens of alveolinids, nummulitids, miliolids as well as discocyclinids and globigerinids, and they were deposited through the Paleocene to early Eocene. This begins the formation known as the Raša Formation, spanning from present day Istria to Konavle. The foraminiferal limestones range from several tens of meters up to two hundred meters or more (Vlahović et al, 2005). The aforementioned basinal facies indicated described local deepening which occurred during the previously described Eocene period. These were separated by shallow-water platforms, creating a number of troughs facing northwest-southeast. Consisting of five to fifty meter thick deep water marls and clay-rich packstones, they mark the transitional deposits between the limestones and overlying flysch (Vlahović et al, 2005). Continual series of uplifting and emersion resulted in erosion which further resulted in deposits of turbidite sandstone and marl in troughs, known as the Eocene Flysch. The thickness of these flysch deposits varies, from 350 meters thick in Istria to 900 meters thick near Zadar.

Today, in Istria, we find primarily Early and Late Cretaceous, as well as Paleogene sediments. Early Cretaceous consists of dark grey and brown, bituminous, thick and platy limestones with occasional dolomite and breccia. The transition to 
Upper Cretaceous is gradual and marked by primarily dolomite and limestone breccia, along with foliated limestones with Ovalveolina ovum. However, the Upper Cretaceous facies vary from basal dolomites, atop which are limestones and breccia, followed by grey and brown limestones, platy limestones and intermissions of dolomites and limestones. Atop everything are light ridge limestones and platy limestones. The emersion phase is characterized with boxites and terra rosa soil, and finally, the Paleogene is represented with freshwater and brackish, followed by marine carbonates and clastic sediments.

The Raša coal mines belong to the Istrian coastal karst. The coal beds are situated at the bottom of the thick complex of Tertiary flysch and limestones, directly above the Upper Cretaceous limestones within a fan-like syncline the dip of which is towards the north (Šarin and Tomašić, 1991; Marković, 2001). They were eroded during the Laramian orogeny, whilst in Early Palaeocene the deposition of the fresh-water and brackish Liburnian strata with coal occurred. The subsequent Early Eocene transgression resulted in the Middle Eocene marine foraminiferal limestones and deepmarine flysch deposits (marls, marly limestones, and sandstones). Later emersion occurred at the end of the Eocene or the beginning of the Oligocene, which caused the folding, thrusting and faulting of coal deposits. Due to deformations and permeable zones in limestones which overlaid and underlaid coal beds, groundwater invaded mining parts and nearly 900,000 tons of coal was forced to be left intact (Šarin and Tomašić, 1991). The deepest galleries of the Istrian mines are at the level of $800 \mathrm{~m}$ below the land, and $500 \mathrm{~m}$ below the sea; these figures are $250 \mathrm{~m}$ and $180 \mathrm{~m}$ in the case of the Raša coal mine, respectively. In 1987, it was decided to stop any further investment due to complex macro- and microtectonics as well as small quantities of coal deposits. Moreover, the environmental legislative regarding sulphur emissions became very strict, whilst the danger imposed by seawater intrusion was quite troublesome. The flooding of the mine was carried out during the period 1988-1991 when the water began to flow out of the mine galleries into the sea.

The Istrian basin, situated on the wider area of Istria, is one of the largest coal bearing basins in Croatia. The base sediments of the basin are Upper Cretaceous, and Paleogene lies on top of these with a mild unconformity. The Istrian Paleocene complex is made up of two large synclines: northern and southern. The northern syncline stretches from Gorica to Rijeka, and the southern syncline, bigger and richer in coal, stretches from Trst to Raša and Podlabin. They are separated from one another by Cretaceous sediments. The main coal-bearing reserves of theIstrian Paleocene are in the southern syncline, near the shores of the Adriatic Sea.

The Istrian Paleocene complex, as seen on the stratigraphic column (see Figure 7), can be divided into four complexes (Pantić and Nikolić, 1973; Nikolić and Dimitrijević, 1981). The first complex is the breccia horizon, representing the base of the coal-bearing Paleocene complex. The age corresponds to the Upper Cretaceous, specifically the transition from Upper Cretaceous to Paleogene. This horizon belongs to the Mali Alan Formation (Velić et al, 2015). The second horizon is the lower-foraminiferal limestones horizon. Here a rich brackish, estuary fauna can be found, with miliolides being the most abundant, Chara oogonia, molluscs and gastropods. These limestones can contain strata of bituminous schists with coal. They mark the beginning of the Raša Formation, which also contains the kozina limestones and upper foraminiferal limestones (Velić et al, 2015). The third horizon is the kozina limestones horizon, represented by grey and dark blue limestones, occasionally limestone breccia. Within this horizon, there are algae oogonia and a large mollusc fauna. It can be divided into two separate levels: Stomatopsis limestones, and Characean limestones. Largely made of gastropods Stomatopsis koziniensis and Stomatopsis crassiocostatus, the first contains a fauna ranging from freshwater to marine, which points to changes during the sedimentation, and the latter contain algae, mainly Chara, are oft bituminous, containing many coal layers. The last horizon is the upper foraminiferal limestones. These represent the transition from sweet water to marine sedimentation with land, brackish and marine fauna. It should be noted that these sediments belong to the Upper Paleocene as well as the Lower Eocene; however, a definite transition is difficult to find. Occasionally, the older horizons are missing, so the upper-foraminiferal limestones along with kozina limestones can often lie directly over eroded karst or bauxite breccia.

Coal is found primarily in the kozina limestones horizon. There are many strata which are in some areas distinctly separated, whereas in others they connect into a single complex coal bed. This makes it difficult to get a definite number of the coal beds, however 13 important coal beds can be singled out (Pantić and Nikolić, 1973; Nikolić and Dimitrijević, 1981) and separated into 3 subgroups: the basal (Cretaceous) group, the middle group and the upper (roof layer) group. The basal group contains five coal beds, ranging from 80 centimeters to 1.35 meters in thickness, the middle group has six beds, 90 centimeters to 2.5 meters thick and the roof layers contain two coal beds, around 80 to 95 centimeters in thickness . Vertically, the distance between one bed and another can be 1 to 2 meters, occasionally up to 15 meters (in the middle and upper subgroups). The coal beds are lens-shaped; the basal group coals have a conchoidal fracture, the middle group coals' fracture is flaky, and the upper group coals have a splintery fracture. 


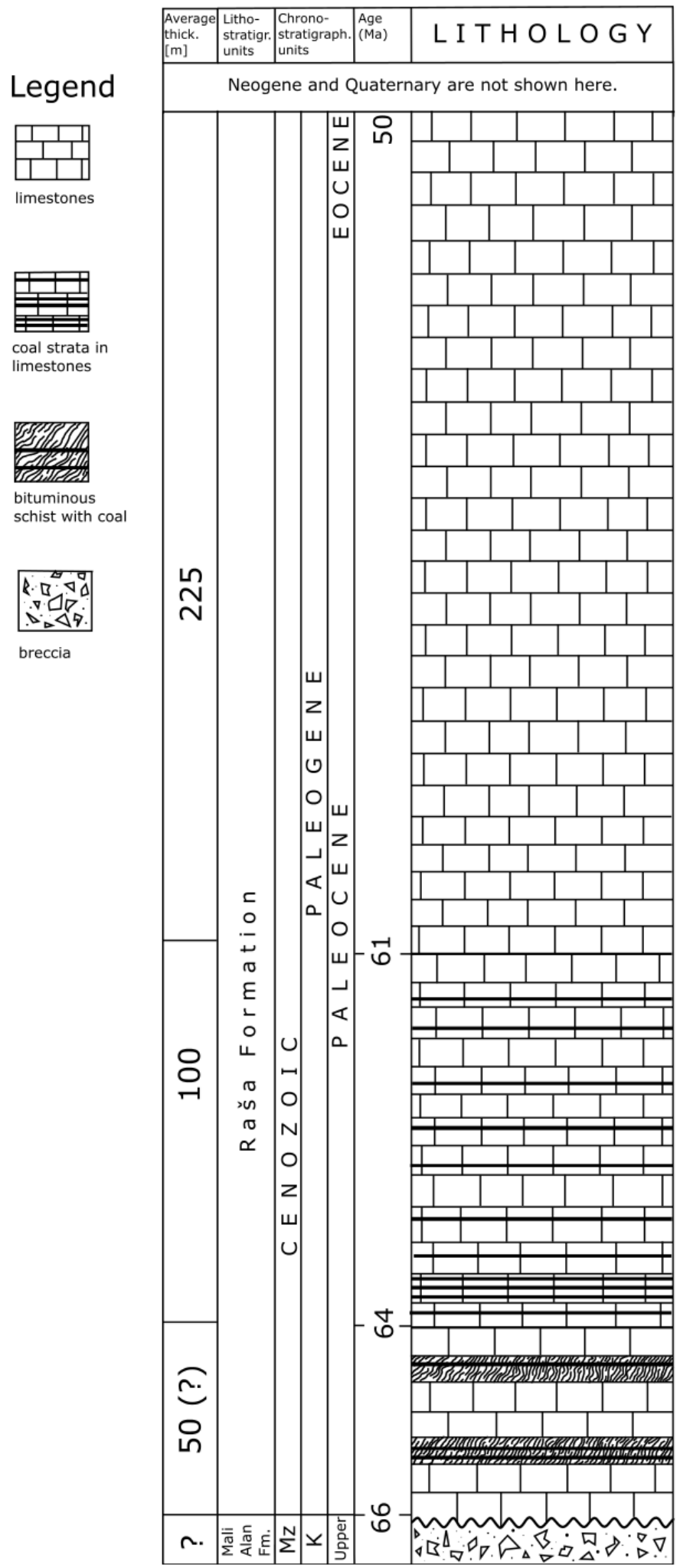

Figure 7. Stratigraphic column of the Istrian basin Lithostratigraphy has been given after Velić et al, 2015. 


\section{Elemental composition of Raša coal and ash}

Raša coal was used in a coal-fired power plant Plomin in its so-called block A during the period 1970-2000 (stack height $120 \mathrm{~m}$ ), whereas imported low-sulphur coals (South America, South Africa, and Asia) have been used in its block B (stack height $340 \mathrm{~m}$ ) since 2000. The past coal combustion activity has resulted in about 1,000,000 tons of waste ash and slag which have been deposited in the vicinity of the plant, covering an area of 120,000 $\mathrm{m} 2$ (Marović et al., 2004). Unlike block A, block B is equipped with emission control technologies, i.e. a flue gas desulphurisation device. Mohorović (2003) reported that block A had emitted nearly 8.5 tons $(18,080 \mathrm{mg} / \mathrm{m} 3$, or $6,900.8 \mathrm{mg} / \mathrm{kg})$ of $\mathrm{SO}_{2}$ during each hour of operation, along with $\mathrm{NOx}, \mathrm{CO}_{2}, \mathrm{CO}$, total suspended particles, and trace elements ( $\mathrm{Ti}, \mathrm{V}, \mathrm{Cr}, \mathrm{Ni}, \mathrm{Cu}, \mathrm{Zn}$, $\mathrm{Se}, \mathrm{Pb}$, etc.). Although the sulphur emissions have dropped significantly with the new block B since 2000, Božičević Vrhovčak et al. (2005) noted that the highest annual $\mathrm{SO}_{2}$ emission still originates from block B (7015 tons, or 5007 $\mathrm{mg} / \mathrm{kWh}$ ), which is the only coal-fired power plant in Croatia. Furthermore, the authors investigated damage to human health resulting from the Croatian thermal power plants annual operation. Following the use of GIS to combine the data on the population density and calculated ambient concentrations of PM, they found out that block B, having occupied second place on the list of the power plants' shares, accounted for $27 \%$ of the total impact. The most notable health endopoints were associated with chronic cough and chronic bronchitis for children, and chronic mortality. Božičević Vrhovčak et al. (2005) also determined that the second largest annual (year 2000) total costs $(6,480,000$ USD) of human health degradation were caused by the Plomin block B. The life cycle of block A was scheduled to end in 2015, and was planned to be replaced by block C (500 MW).

In addition to its high $\mathrm{S}$ values (up to 12-14\%), Raša coal was also characterised by an increased radioactivity. The activity of U-238 was $500-1200 \mathrm{~Bq} / \mathrm{kg}$ in the $1970 \mathrm{~s}$, and $250-300 \mathrm{~Bq} / \mathrm{kg}$ in the $1980 \mathrm{~s}$, which was $10-15$ times higher than the average of other types of coal in the world (Marović et al., 2004). According to Bauman and Horvat (1981), natural $U$ in the Raša coal ranged $14-100 \mathrm{mg} / \mathrm{kg}$ (occasionally up to $1500 \mathrm{mg} / \mathrm{kg}$ ), whilst technologically enhanced natural radioactivity of ash and slag was raised by a factor of ten. The authors also reported that the ash contained U238, Th-236, Ra-226, Pb-210, Rn-222, Rn-220, as well as sulphur bound to the mineral particles. During the 1990s, the immediate surroundings of the plant (inside its fence) underwent in situ restoration measures, which involved covering the bare waste pile with a soil layer, and the construction of a drainage system and a retention pool. The outcome of these clean-up measures has been an improved environmental situation in regard to radioactivity (Marović et al., 2004). Scientists from the Ruđer Bošković Institute in Zagreb (Division of Experimental Physics, Laboratory for Ion Beam Interactions) conducted numerous measurements and experiments on Raša coal and ash samples during the 1980s and 1990s (Jakšić et al., 1993; Valković et al., 1995). By means of XRF, PIXE and radioactive source (109Cd) techniques, Valković et al. (1984a) successfully measured elements, i.e. $\mathrm{S}, \mathrm{K}, \mathrm{Ca}, \mathrm{Ti}, \mathrm{V}, \mathrm{Cr}, \mathrm{Fe}, \mathrm{Ni}, \mathrm{Cu}, \mathrm{Zn}, \mathrm{As}, \mathrm{Se}, \mathrm{Rb}, \mathrm{Sr}, \mathrm{Mo}$, and $\mathrm{U}$ in Raša coal samples, and reported the following values (all in $\mathrm{mg} / \mathrm{kg}$, except for $\mathrm{S}$ and $\mathrm{Ca}$ in \%): 13.05, 532, 1.8, 380, 43, 23, 3300, 23, 25, 41, 25, 43, 13, 412, 94, and 55, respectively. Valković et al. (1984b) analysed Raša fly ash samples by means of PIXE and XRF. They measured the elements $\mathrm{S}, \mathrm{Ca}, \mathrm{Ti}, \mathrm{V}, \mathrm{Cr}, \mathrm{Fe}, \mathrm{Ni}, \mathrm{Cu}, \mathrm{Zn}, \mathrm{Ga}, \mathrm{As}, \mathrm{Se}, \mathrm{Pb}, \mathrm{Rb}$, $\mathrm{U}, \mathrm{Sr}$, and $\mathrm{Y}$, and reported the following values (all in $\mathrm{mg} / \mathrm{kg}$, except for $\mathrm{S}, \mathrm{Ca}$ and $\mathrm{Fe}$ in \%): 1.3, 7.8, 1204, 969, 439, $2.2,65,72,37,10,21,78,19,16,207,1809$, and 11, respectively. Based on these measurements, Limić and Valković (1986) made some statistical calculations in order to find certain relationships of trace element levels in a profile of a coal seam. Hereby, they were able to find out that $\mathrm{Ca}, \mathrm{S}, \mathrm{Fe}, \mathrm{Ti}$, and $\mathrm{V}$ had the same genesis in the investigated coal seam. Stergaršek et al. (1988) investigated the potential adsorption of $\mathrm{SO}_{2}$ on fly ash, and related problems regarding sulphur emission control technology which was planned to be implemented in the coal-fired power plant's block B. They also pointed out that the alkaline Raša ash was considered as a valuable source of uranium (U) and vanadium (V). Vajić et al. (1990) determined the elemental distribution pattern on the coal-rock interface as a basis for the investigation of possible diffusion processes on that specific boundary region.

In regard to the physical composition of Raša coal, its values of moisture, ash, fixed $\mathrm{C}$, volatiles, total $\mathrm{S}$, pyrite $\mathrm{S}$, sulphate $\mathrm{S}$, and organic $\mathrm{S}$ were commonly reported as follows (in \%): 1.12, 11.99, 42.89, 44.00, 10.30, 0.46, 0.03, and 9.81, respectively (personal communication and documentation - Istarski ugljenokopi Raša) (see Figure 5). 


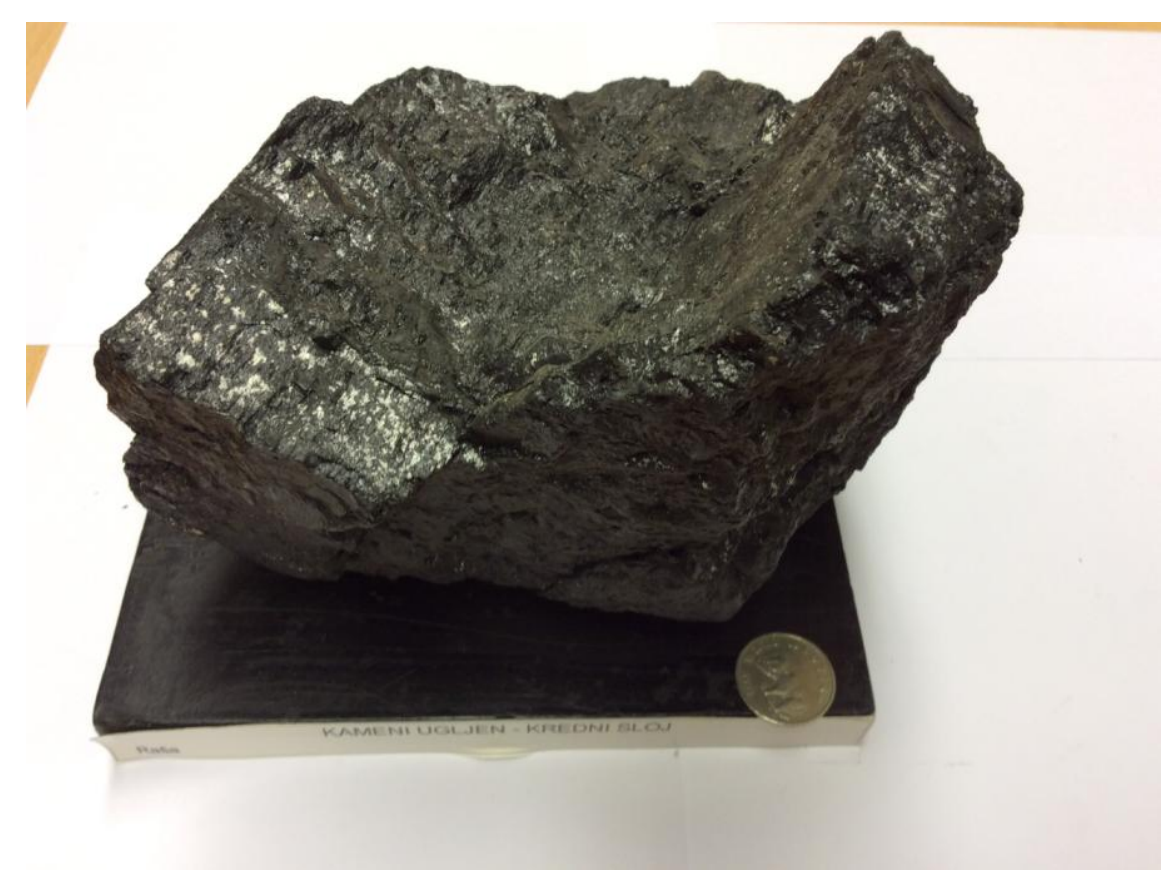

Figure 8. Coal sample from the Raša mine

Photo taken by Prof. Dr. Tomislav Malvić, Faculty of Mining, Geology and Petroleum Engineering, currently presented in the Faculty of Mining, Geology and Petroleum Engineering collection

\section{Environmental consequences of Raša coal combustion processes}

In evaluating the previous literature aimed at the potential influence of the power-plant Plomin on its surroundings, it has been revealed that the locality had been studied primarily by radiometric methods. Trace metal distribution was scarcely studied regarding links with coal-fired power plant, whilst the site-specific distribution of sulphur and PAHs in soil as a possible plant's legacy has been reported only recently. They are all briefly presented in the following text.

Bauman and Horvat (1981) examined surface contamination of the power plant's workers and equipment exposed to enhanced levels of naturally occurring radionuclides. They found increased levels of $\mathrm{Pb}$ in urine and chromosome aberrations, and concluded that the hazards from exposure even to low doses of natural radiation by intake, inhalation and surface contamination could not be neglected. (see Figure 6.) Lokobauer et al. (1997) investigated radon (Rn) activity concentration in houses around the power plant upon the assumption that certain old houses in the region were built with material prepared from the Raša coal ash. They found out that the assumption was true as the average Rn activity concentrations in the old houses were $55-426 \mathrm{~Bq} / \mathrm{m} 3$, whilst in new ones $16-67 \mathrm{~Bq} / \mathrm{m} 3$. Oreščanin et al. (2002) examined potential mutagenesis of the sea bottom sediments from the Plomin Bay, and found no mutagenic effect of metals. Oreščanin et al. (2009) point out that the deposited material in the Plomin Bay poses a low environmental health risk due to low heavy metal concentrations. Marović et al. (2004, 2006) assessed the radiological situation in the area of the power plant Plomin which was found to be improved due to remedial actions during the late 1990s. Medical studies established the correlation between ground $\mathrm{SO}_{2}$ levels and health problems of pregnant women and small children (Mohorović, 2003; 2004; 2008a, b; 2010; 2012). Namely, Croatian gynaecologist Mohorović (2003) determined that methemoglobin in pregnant women (who lived within the 3.5-12 km distance from the plant), which is a result of exposure to toxic substances in the environment, was positively correlated with $\mathrm{SO}_{2}, \mathrm{NOx}$, and other coal combustion products. Also, Mohorović (2004) confirmed the role of inhaled environmental toxins in the early development of the human embryo as well as in an adverse pregnancy course caused by permanent oxidative stress, misbalanced production of reactive oxygen species, reactive nitrogen species, reactive sulphur species, and other unfavourable metabolic processes on early embryogenesis, resulting in growth-arrested cells. Prohić and Miko (1998) found increased levels of $\mathrm{Se}$ and $\mathrm{Cr}$ in soil samples collected in the vicinity of the power plant from an approximate radius of $1.2 \mathrm{~km}$. Miko et al. (2003) applied the BCR extraction on one soil profile near the plant so as to understand the metal mobility into the karst aquifer groundwater. Potočić and Seletković (2001), Potočić et al. (2003), and Cesar et al. (2005) investigated the possible consequences of sulphur concentration on the physiological status of pine needles 
collected from different distances around the power plant. Recently, several studies (Medunić et al., 2014; 2015a, b; Ernečić et al., 2014) have been focused on site specific distribution of sulphur, PAHs, and trace elements in topsoil around the power plant taking into account the direction of the prevailing winds in the area, and an assessment of the cytotoxic and genotoxic potential of water extracts of the soil. They found that the soil around the power plant Plomin is severely polluted with S and polycyclic aromatic hydrocarbons (PAHs) (Medunić et al., 2015a) as well as with Ra-226 (Ernečić et al., 2014). Their ongoing analytical research is focused on mineral phases in topsoil samples which might be indicative of coal combustion, then leaching experiments, phytotoxicity, stable isotope analysis, and some other analytical methods so as to envisage its geochemical status which is very interesting indeed.

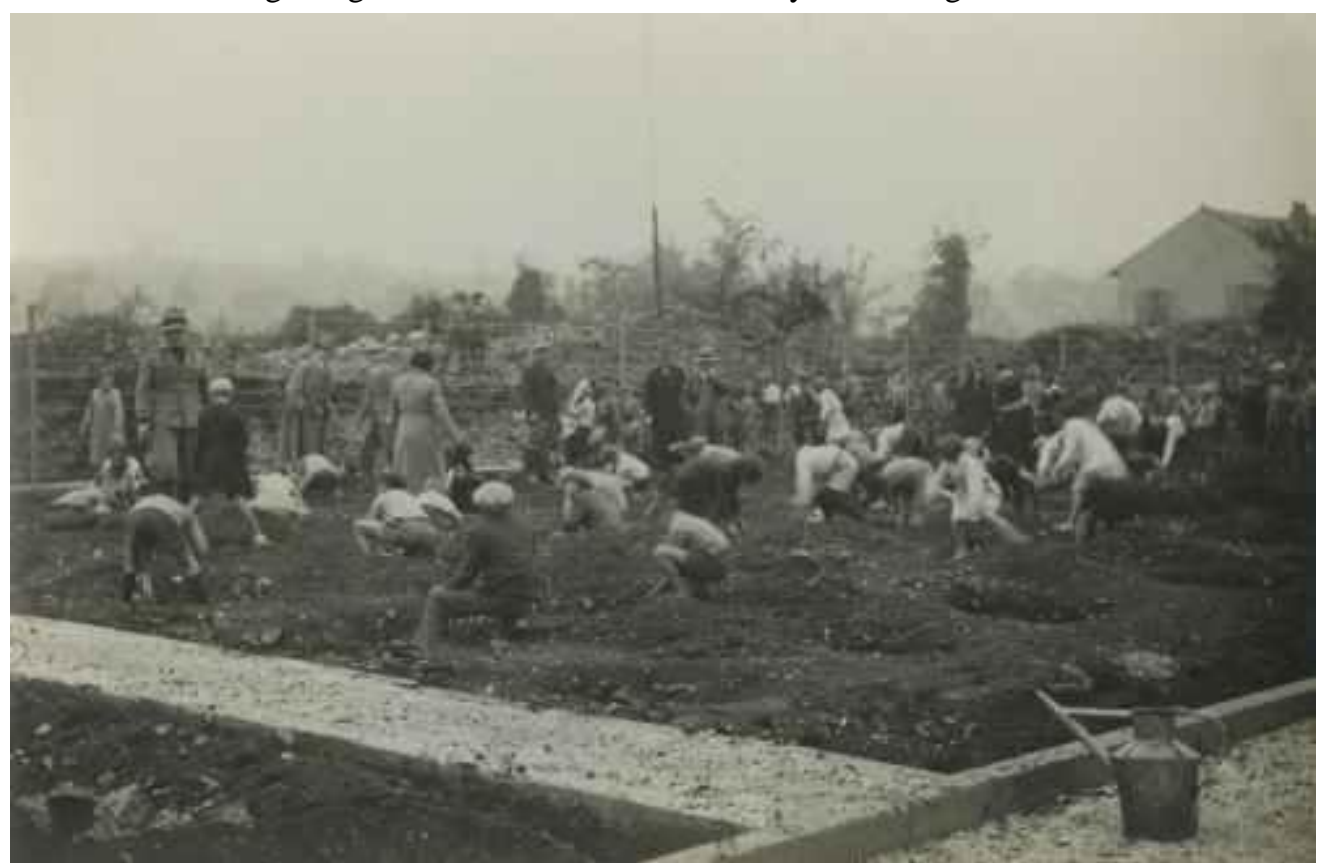

Figure 9. Children separating the coal, $20^{\text {th }}$ century

Taken from URL: http://vmrii.com/hr/microsite/rudarstvo/

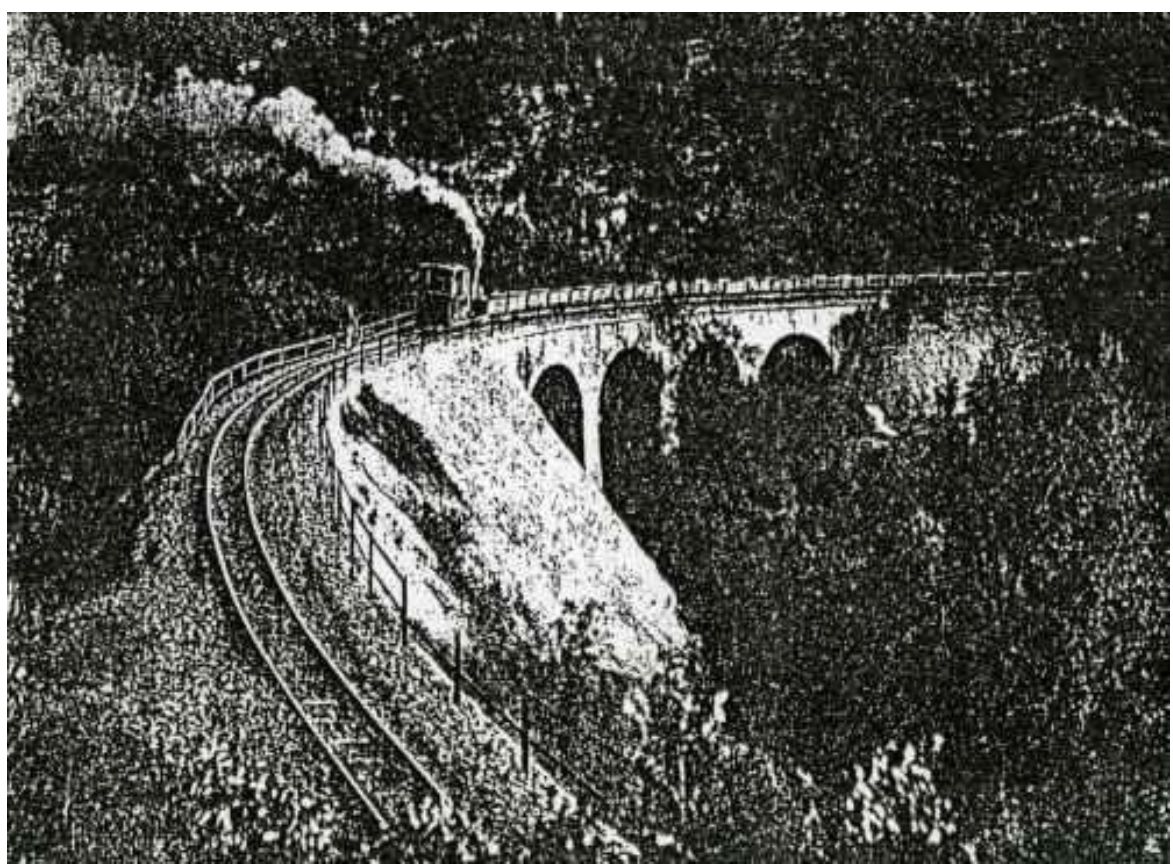

Figure 10. Transport of the coal, $2 \mathrm{o}^{\text {th }}$ century (http://vmrii.com/hr/microsite/rudarstvo/) 


\section{Conclusion}

Coal is the fuel that initiated and maintained the Industrial Revolution. Moreover, it prevalently drives the modern electricity infrastructure in the world which craves energy. However, coal is definitely a dirty fuel and scientists are expected to highly improve the clean coal technology in the foreseeable future. Also, human society should strive towards energy efficient solutions in all life domains. Regarding coal mining in the Labin area - it should not be forgotten as its past was grand. Raša coal had fed not only furnaces of the power plant Plomin, smelting and other industrial factories, but also scientists' interest in this marvellous nature's invention. So, hats off to Raša coal.

\section{Acknowledgment}

The first author is grateful to dr. sc. Ivanka Lovrenčić Mikelić (IRB), dr. sc. Milko Jakšić (IRB), dr. sc. Stjepko Fazinić (IRB), dr. sc. Iva Božičević Mihalić (IRB), prof. dr. sc. Nenad Tomašić (PMF), dr. sc. Nevenka Kopjar (IMI), prof. dr. sc. Višnja Gaurina Srček (PBF), dr. sc. Željka Fiket (IRB), prof. dr. sc. Marijan Ahel (IRB), doc. dr. sc. Sandra Radić Brkanac (PMF), dr. sc. Alica Bajić (DHMZ), and friends Višnja Oreščanin and Dražen Vratarić for all the help, advice, resources, support, and fruitful scientific ideas. Also, many thanks to ex-students Gorana Ernečić, Ana Velić, Barbara Bertović, and Tonći Urošević.

\section{References}

Abadie, L.M., Chamorro, J.M. (2009): Income risk of EU coal-fired power plants after Kyoto. Energy Policy, 37, 5304-5316.

Adriano, D.C., Page, A.L., Elseewi, A.A., Chang, A.C., Straughan, I. (1980): Utilization and disposal of fly ash and other coal residues in terrestrial ecosystems: a review. Journal of Environmental Quality, 9, 333-344.

Álvarez-Ayuso, E., Querol, X., Tomás, A. (2006): Environmental impact of a coal combustion-desulphurisation plant: Abatement capacity of desulphurisation process and environmental characterisation of combustion by-products. Chemosphere, 65, 20092017.

Amdur, M. O., Sarofim, A. F., Neville, M., Quann, R. J., McCarthy, J. F., Elliott, J. F., Lam, H. F., Rogers, A. E., Conner, M. W. (1986): Coal combustion aerosols and $\mathrm{SO}_{2}$ : an interdisciplinary analysis. Environ. Sci. Technol. 20, 138-145.

Attar, A. (1978): Chemistry, thermodynamics and kinetics of reactions of sulphur in coal-gas reactions: A Review. Fuel, 57, $201-212$.

Badr, O., Probert, S.D. (1994): Atmospheric sulphur: trends, sources, sinks and environmental impacts. Applied Energy, 47, 1-67.

Banerjee, T., Murari, V., Kumar, M., Raju, M.P. (2015): Source apportionment of airborne particulates through receptor modeling: Indian scenario. Atmospheric Research, 164-165, 167-187.

Baruah, B.P., Khare, P. (2010): Mobility of trace and potentially harmful elements in the environment from high sulfur Indian coal mines. Applied Geochemistry, 25, 1621-1631.

Bauman, A. and Horvat, Đ. (1981): The impact of natural radioactivity from a coal-fired power plant. The Science of the Total Environment, 17, 75-81.

Boudou, J.P., Boulègue, J., Maléchaux, L., Boon, J.J. (1987): Identification of some sulphur species in a high organic sulphur coal. Fuel 66(11):1558-1569.

Božičević Vrhovčak, M., Tomšić, Ž. and Debrecin, N. (2005): External costs of electricity production: case study Croatia. Energy Policy, 33, 1385-1395.

Breger, I.A. (1958): Geochemistry of coal. Economic Geology, 53, 823-841.

Brimblecombe, P. (2014): The global sulfur cycle. Treatise on Geochemistry, 2nd edition.

Casagrande D.J. (1977): Sulphur in peat and coal. In Coal and coal-bearing strata: recent advances (ed: Scott A.C.), Geological Society Special Publication No. 32, 87-105.

Cesar, V., Užarević, Z., Potočić, N., Seletković, I., Lepeduš, H. (2005): Preliminary report on epicuticular wax structure in Black pine needles affected by $\mathrm{SO}_{2}$ emitted from thermal power plant Plomin (Croatia). Periodicum Biologorum, 107, 357-360.

Chaput, D.L., Hansel, C.M., Burgos, W.D., Santelli, C.M. (2014): Profiling microbial communities in manganese remediation systems treating coal mine drainage. Applied and Environmental Microbiology, 81, 2189-2198.

Chou C.-L. (1997): Geologic factors affecting the abundance, distribution, and speciation of sulfur in coals. In: Proc. 30th Int'l Ge ol. Congr., (ed: Qi Y.), Vol. 18, Part B, 47-57.

Chou, C.-L. (2012): Sulfur in coals: A review of geochemistry and origins. International Journal of Coal Geology, 100, 1-13.

Csavina, J., Field, J., Taylor, M.P., Gao, S., Landázuri, A., Betterton, E.A., Sáez, A.E. (2012): A review on the importance of metals and metalloids in atmospheric dust and aerosol from mining operations. Sciene of the Total Environment, 433, 58-73.

Cuddihy, R.G. (1983): Risk assessment relationships for evaluating effluents from coal industries. The Science of the Total Environment, 28, 479-492.

Dai, S., Ren, D., Tang, Y., Shao, L. and Li, S. (2002): Distribution, isotopic variation and origin of sulfur in coals in the Wuda coalfield, Inner Mongolia, China. International Journal of Coal Geology, 51, 237 - 250. 
Dai, S., Ren, D., Zhou, Y., Chou, C.-L., Wang, X., Zhao, L., Zhu, X. (2008): Mineralogy and geochemistry of a superhigh-organicsulfur coal, Yanshan Coalfield, Yunnan, China: evidence for a volcanic ash component and influence by submarine exhalation. Chemical Geology, 255, 182-194.

Dämmgen, U., Walker, K., Grünhage, L., Jäger, H.-J. (1998): The atmospheric sulphur cycle. In Sulphur in Agroecosystems, Schnug, E. (ed.), 75-114.

Dowarah, J., Deka Boruah, H.P., Gogoi, J., Pathak, N., Saikia, N., Handique, A.K. (2009): Eco-restoration of a high-sulphur coal mine overburden dumping site in northeast India: A case study. Journal of Earth System Science, 118, 597-608.

Duić, N., Juretić, F., Zeljko, M. and Bogdan, Ž. (2005): Croatia energy planning and Kyoto Protocol, Energy Policy, 33, $1003-1010$.

Dunham, J.T., Rampacek, C., Henrie, T.A. (1975): High-sulfur coal for generating electricity. Science, 189, 346-351.

Ellsaesser, H.W. (1981): Statement prepared for presentation at the hearings on consolidation coal company's petition to amend the primary ambient air quality standards for sulfur dioxide. The Science of the Total Environment, 19, 13-19.

EMEP/EEA (2013): EMEP/EEA air pollutant emission inventory guidebook, EEA Technical report No 12/2013.

Ernečić, G., Lovrenčić Mikelić, I. and Medunić, G. (2014): Distribution of ${ }^{226} \mathrm{Ra}$ in the surface soil in the vicinity of the thermal power plant Plomin (Croatia). In: Pál-Molnár E. (ed), Acta Mineralogica-Petrographica, Abstract Series. Szeged, Hungary, 2828.

Flues, M., Sato, I.M., Scapin, M.A., Cotrim, M.E.B., Camargo, I.M.C. (2013): Toxic elements mobility in coal and ashes of Figueira coal power plant, Brazil. Fuel, 103, 430-436.

Fowler, D., Smith, R., Muller, J., Cape, J.N., Sutton, M., Erisman, J.W., Fagerli, H. (2007): Long term trends in sulphur and nitrogen deposition in Europe and the cause of non-linearities. Water, Air, and Soil Pollution, 7, 41-47.

Galloway, J.N. (1995): Acid deposition: perspectives in time and space. Water, Air and Soil Pollution, 85, 15-24.

Glass, N.R. (1979): Environmental effects of increased coal utilization: ecological effects of gaseous emissions from coal combustion. Environmental Health Perspectives, 33, 249-272.

Guijian, L., Zicheng, P., Pingyu, Y. and Guilian, W. (2001): Sulfur in Coal and Its Environmental Impact from Yanzhou Mining District, China. Chinese Journal of Geochemistry, 20, 273-281.

Hamrla, M., Rudarsko-Metalurški Zbornik, 1960., 3, 203-216

Jakšić, M., Bogdanović, I., Ceereda, E., Fazinić, S., Valković, V. (1993): Quantitative PIXE analysis of single fly ash particles by a proton microbeam. Nuclear Instruments and Methods in Physical Research B, 77, 505-508.

Jalilehvand, F. (2006): Sulfur: not a 'silent' element any more. Chem Soc Rev, 35, 1256-1268.

Judkins, R.R., Fulkerson, W., Sanghvi, M.K. (1993): The dilemma of fossil fuel use and global climate change. Energy \& Fuels, 7 , $14-22$.

Kampa, M. and Castanas, E. (2008): Human health effects of air pollution. Environmental Pollution 151, 362-367.

Kasrai, M., Brown, J.R., Bancroft, G.M., Yin, Z. and Tan, K.H. (1996): Sulphur characterization in coal from X-ray absorption near edge spectroscopy. International Journal of Coal Geology, 32, 107- 135.

Kirby, B.M., Vengadajellum, C.J., Burton, S.G. and Cowan, D.A. (2010): Coal, Coal Mines and Spoil Heaps. Handbook of Hydrocarbon and Lipid Microbiology, 2277-2292.

Komarnisky, L.A., Christopherson, R.J., Basu, T.K. (2003): Sulfur: Its clinical and toxicologic aspects. Nutrition, 19, 54-61.

Koptsik, G., Alewell, C. (2007): Sulphur behaviour in forest soils near the largest SO2 emitter in northern Europe. Applied Geochemistry, 22, 1095-1104.

Kuklińska, K., Cieszynska, M., Wolska, L., Namiesnik, J. (2013): Analytical and bioanalytical problems associated with the toxicity of elemental sulfur in the environment. Trends in Analytical Chemistry, 48, 14-21.

Kumar, M., Singh, R.S., Banerjee, T. (2015): Associating airborne particulates and human health: Exploring possibilities. Environment International, http://dx.doi.org/10.1016/j.envint.2015.06.002

Lalonde, R.T., Ferrara, L.M., Hayes, M.P. (1987): Org. Geochem., 11, 563-571

Larson, L.N., Sánchez-España, J., Burgos, W. (2015): Rates of low-pH biological Fe(II) oxidation in the Appalachian bituminous coal basin and the Iberian pyrite belt. Applied Geochemistry, 47, 85-98.

Laumbach, R., Meng, Q., Kipen, H. (2015): What can individuals do to reduce personal health risks from air pollution? J Thorac Dis, 7, 96-107.

Limić, N., Valković, V. (1986): The occurrence of trace elements in coal. Fuel, 65, 1099-1102.

Llorens, J.F., Fernández-Turiel, J.L., Querol, X. (2001): The fate of trace elements in a large coal-fired power plant. Environmental Geology, 40, 409-416.

Lokobauer, N., Franić, Z., Senčar, J., Bauman, A. and Sokolović, E. (1997): Radon concentrations in houses around the Plomin coalfired power plant. Journal of environmental radioactivity, 34, 37-44.

Manowitz, B., Lipfert, F.W. (1990): Environmental aspects of the combustion of sulfur-bearing fuels. In Geochemistry of Sulfur in Fossil Fuels, Orr W. et al. (eds), ACS Symposium Series, American Chemical Society, Washington DC, 53-67.

Markandya, A., Wilkinson, P. (2007): Electricity generation and health. The Lancet, 370, 979-990.

Marković, S. (2002): Hrvatske mineralne sirovine (Croatian mineral ores), HGI, Zagreb, pp. 544.

Marović, G., Senčar, J., Bronzović, M., Franić, Z., Kovač, J. (2006): Otpad vezan uz proizvodnju električne energije i proizvodnju mineralnih gnojiva. Arhiv za Higijenu Rada i Toksikologiju, 57, 333-338.

Marović, G., Senčar, J., Kovač, J. and Prlić, I. (2004): Improvement of the radiological environmental situation due to remedial actions at a coal-fired power plant. Journal of Radioanalytical and Nuclear Chemistry, 261, 451-455.

Martins, V., Minguillón, M.C., Moreno, T., Querol, X., de Miguel, E., Capdevila, M., Centelles, S., Lazaridis, M. (2015): Deposition of aerosol particles from a subway microenvironment in the human respiratory tract. Journal of Aerosol Science, 90, 103-113. 
Masto, R.E., Ram, L.C., George, J., Selvi, V.A., Sinha, A.K., Verma, S.K., Rout, T.K., Prabal, P (2011): Impacts of opencast coal mine and mine fire on the trace elements' content of the surrounding soil vis-a-vis human health risk. Toxicological \& Environmental Chemistry, 93, 223-237.

McConnell, J.R., Edwards, R. (2008): Coal burning leaves toxic heavy metal legacy in the Arctic. PNAS, 105, $12140-12144$.

Medunić, G., Božičević Mihalić, I., Ahel, M., Kopjar, N., Gaurina Srček, V., Fiket, Ž. and Mikac, I. (2015a): Toxicity risk assessment of sulfur and PAHs in soil surrounding a coal-fired power plant. Proceedings of 27th IAGS, Bowell R.J., Cox M. (eds), Tucson, USA, 1-17.

Medunić, G., Božičević Mihalić, I., Kopjar, N., Gaurina Srček, V., Cuculić V. and Oreščanin, V. (2014): Sulphur soil pollution caused by a coal-fired power plant (Plomin, Croatia). In: Belviso C., Saverio F., Gianossi M. L. (eds) Book of abstracts of International Conference on atmospheric dust (DUST 2014), 276-276.

Medunić, G., Fiket, Ž., Kniewald, G. (2015b): Rare earth elements distribution in soil nearby Plomin thermal power plant (Croatia). Proceedings of 27th IAGS, Bowell R.J., Cox M. (eds), Tucson, USA, 1-9.

Miko, S., Durn, G., Adamcová, R., Čović, M., Dubíková, M., Skalský, R., Kapelj, S., Ottner, F. (2003): Heavy metal distribution in karst soils from Croatia and Slovakia. Environmental Geology, 45, 262-272.

Mohorović, L. (2003): The level of maternal methemoglobin during pregnancy in an air-polluted environment. Environmental Health Perspectives, 111, 1902-1905.

Mohorović, L. (2004): First two months of pregnancy - critical time for preterm delivery and low birthweight caused by adverse effects of coal combustion toxics. Early Human Development, 80, 115-123.

Mohorović, L. (2008a): Impact of environmental toxics and of meteorological conditions on reproductive loss and stillbirth. Gynaecologia et Perinatologia, 17(3), 133-137.

Mohorović, L., Materljan, E., Brumuni, G. (2008b): Are neonatal jaundice, heart murmur, dyslalia and learning/memory impairments consequences of mother exposure to environmental oxidants? 'The fetus as a patient', XXIV International Congress, Frankfurt, Germany, June 12-14 2008, 111-115.

Mohorović, L., Materljan, E., Mićović, V., Malatestinić, Đ., Štifter, S., Lavezzi, A.M. (2012): Impacts of exogenously derived nitrogen oxide and sulfur compounds on the structure and function of the vascular endothelium link pregnancy hypertension with later life hypertension. Journal of Hypertension, 1, 1-6.

Mohorović, L., Petrović, O., Haller, H., Mićović, V. (2010): Pregnancy loss and maternal methemoglobin levels: an indirect explanation of the association of environmental toxics and their adverse effects on the mother and the fetus. International Journal of Environmental Research and Public Health, 7, 4203-4212.

Mukherjee, S. and Srivastava, S.K. (2005): Trace elements in high-sulfur Assam coals from the Makum coalfield in the northeastern region of India. Energy \& Fuels, 19, 882-891.

Nemery, B., Hoet, P.H.M., Nemmar, A. (2001): The Meuse Valley for of 1930: an air pollution disaster. The Lancet, 357, 704-708.

Nikolić, P., Dimitrijević D. (1981): Ugalj Jugoslavije. Zavod za udžbenike i nastavna sredstva, Beograd, 418 str.

Oden, S. (1976): The acidity problem - an outline of concepts. Water, air and soil pollution, 6, 137-166.

Oreščanin, V., Franekić-Čolić, J., Durgo, K., Valković, V. (2002): Investigation of mutagenic effect of metals in the Plomin Bay sediments by modified preincubation ames assay. Journal of Trace and Microprobe Techniques, 20, 69-77.

Oreščanin, V., Nađ, K., Bartolinčić, A., Valković, V. (2009): Chemical profile of Plomin Bay sediments. Arhiv za Higijenu Rada i Toksikologiju, 60, 281-287.

Pantić, N., Nikolić, P. (1973): Ugalj. Naučna knjiga, Beograd, 563 str.

Potočić, N., Seletković, I. (2001): Determination of the level of sulphur deposition in Istria by means of bioindication. Šumarski list, 9/10, CXXV, 487-494.

Potočić, N., Seletković, I., Lepeduš, H. and Cesar, V. (2003): Recovery of black pine (Pinus nigra Arn.) needles in response to lowered $\mathrm{SO}_{2}$ in the air - a case study of Plomin thermal power plant (Croatia). Periodicum Biologorum, 105, 319-323.

Prohić, E., Miko, S. (1998): Distribution of selected elements in soils in the vicinity of the coal burning power plant "Plomin", Istria, Croatia. In: Erdwissenschaftliche Aspekte des Umweltschutzes, Tagungsband. Sauer, D. (ed.), Wien, Österriechisches Forschungs und Prüfzentrum Arsenal Ges. m. b., 319-324.

Querol, X., Alastuey, A., Lopez-Soler, A., Mantilla, E., Plana, F. (1996): Mineral composition of atmospheric particulates around a large coal-fired power station. Atmospheric Environment, 30, 3557-3572.

Querol, X., Fernandez Turiel, J.L., Lopez Soler, A., Duran, M.E. (1992): Trace elements in high-S subbituminous coals from the Teruel mining district, northeast Spain. Applied Geochemistry, 7, 547-561.

Querol, X., Fernández-Turiel, J.L., López-Soler, A. (1995): Trace elements in coal and their behaviour during combustion in a large power station. Fuel, 74, 331-343.

Rađenović, A. (2004): Sulfur in coal. Kemija u industriji, 53, 557-565.

Rađenović, A. (2006): Inorganic constituents in coal. Kemija u industriji, 55, 65-71.

Rall, D. (1974): Review of the health effects of sulfur oxides. Environmental Health Perspectives, 8, 97-121.

Saikia, B.K., Hower, J.C., Hood, M.M., Baruah, R., Dekaboruah, H.P., Boruah, R., Sharma, A. and Baruah, B.P. (2015): Petrological and biological studies on some fly and bottom ashes collected at different times from an Indian coal-based captive power plant. Fuel, 158, 572-581.

Schindler, D.W. (1988): Effects of acid rain on freshwater ecosystems. Science, 239, 4836, 149-157.

Shafiee, S., Topal, E. (2009): When will fossil fuel reserves be diminished? Energy Policy, 37, 181-189.

Silva, L.F.O., DaBoit, K., Sampaio, C.H., Jasper, A., Andrade, M.L., Kostova, I.J., Waanders, F.B., Henke, K.R., Hower, J.C. (2012): The occurrence of hazardous volatile elements and nanoparticles in Bulgarian coal fly ashes and the effect on human health exposure. Science of the Total Environment, 416, 513-526. 
Sinninghe Damsté, JS, White CM, Green, J.B., de Leeuw JW (1999): Organosulfur compounds in sulfur-rich Raša coal. Energy \& Fuels, 13, 728-738.

Smith, S.J., van Aardenne, J., Klimont, Z., Andres, R.J., Volke, A., Delgado Arias, S. (2011): Anthropogenic sulfur dioxide emissions: 1850-2005. Atmos Chem Phys, 11, 1101-1116.

Speight, J. (2005): Handbook of coal analysis. John Wiley \& Sons, Inc., Hoboken, New Jersey, 222 pg.

Speight, J.G. (2013): Coal-Fired Power Generation Handbook. Scrivener Publishing LLC, Salem, 8-21.

Stergaršek, A., Valković, V., Injuk, J. (1988): Sposobnost pepela rakog ugljena z vezivanje sumpor-dioksida iz dimnog plina termoelektrane. Zaštita atmosfere, 16, 6-8.

Šarin, A., Tomašić, M. (1991): Hydrogeological review of the Raša coal mine in the coastal karst of Croatia. 4th International Mine Water Congress, Ljubljana, Slovenia, Yugoslavia, September 1991.

Tang, S., Sun, S., Qin, Y., Jiang, Y., Wang, W. (2008): Distribution characteristics of sulfur and the main harmful trace elements in China's coal. Acta Geologica Sinica, 82, 722-730.

Thibodeau, L.A., Reed, R.B., Bishop, Y.M.M., Kammerman, L.A. (1980): Air pollution and human health: a review and reanalysis. Environmental Health Perpectives, 34, 165-183.

Thielemann, T., Schmidt, S., Gerling, P. (2007): Lignite and hard coal: energy suppliers for world needs until the year $2100-$ an outlook. International Journal of Coal Geology, 72, 1-14.

U.S. EPA (U.S. Environmental Protection Agency) (1990): Clean Air Act Amendments of 1990; 1st Congress (1989-1990); U.S. EPA: Washington, DC.

Vajić, M., Jakšić, M., Fazinić, S., Valković, V., Grime, G.W., Watt, F. (1990): Studies of trace element distribution at the coal-rock interface. Nuclear Instruments and Methods in Physical Research B, 49, 336-339.

Valković, V., Makjanić, J., Jakšić, M., Popović, S., Bos, A.J.J., Vis, R.D., Wiederspahn, K. and Verheul, H. (1984a): Analysis of fly ash by $\mathrm{X}$-ray emission spectroscopy and proton microbeam analysis. Fuel, 63, 1357-1362.

Valković, V., Orlić, I., Makjanić, J., Rendić, D., Miklavžič, U. and Budnar, M. (1984b): Comparison of different modes of excitation in X-ray emission spectroscopy in the detection of trace elements in coal and coal ash. Nuclear Instruments and Methods in Physics Research B4, 127-131.

Valković, O., Jakšić, M., Fazinić, S., Valković, V., Moschini, G., Menapace, E. (1995): Quality control of PIXE and PIGE nuclear analytical techniques in geological and environmental applications. Nuclear Instruments and Methods in Physical Research B, 99, 372-375.

Vejahati, F., Xu, Z., Gupta, R. (2010): Trace elements in coal: Associations with coal and minerals and their behavior during coal utilization - A review. Fuel, 89, 904-911.

Velić, J., Malvić, T., Cvetković, M., Velić I. (2015): Stratigraphy and petroleum geology of the Croatian part of the Adriatic basin. Journal of Petroleum Geology, vol. 38 (3), July 2015, pp 281-300.

Vorano, T. (1997): Istarski ugljenokopi, četiri stoljeća rudarenja u Istri. $190 \mathrm{str}$.

White C.M., Douglas L.J., Anderson R.R., Schmidt C.E., Gray R.J. (1990): Organosulfur constituents in Rasa coal. In Geochemistry of sulfur in fossil fuels (eds: Orr W. et al.), ACS Symposium Series; American Chemical Society, Washington, DC, 429,261286.

White, C.M., Douglas, L.J., Schmidt, C., Hackett, M. (1998): Formation of polycyclic thiophenes from raction of selected polycyclic aromatic hydrocarbons with elemental sulfur and/or pyrite under mild conditions. Energy and Fuels, 2, 220-223

WHO (1982): Sulfur oxides and suspended particulate matter. Environmental Health Criteria 8, Geneva.

Xu, M., Yan, R., Zheng, C., Qiao, Y., Han, J., Sheng, C. (2003): Status of trace element emission in a coal combustion process: a review. Fuel Processing Technology, 85, 215-237. 


\section{Sažetak}

\section{Nekada velik, danas zaboravljen: Što znamo o raškome ugljenu, iznimno bogatome organskim sumporom?}

Istarski ugljenokopi, smješteni na istočnome dijelu istarskoga poluotoka (sjeverni Jadran, Hrvatska), bili su najvažnija i gospodarski najvrednija ležišta kamenoga ugljena u Hrvatskoj od 18. stoljeća sve do 1999. godine, kada je prestalo njihovo iskapanje i uporaba u TE Plomin. Ugljen se nalazi unutar paleocenskih kozinskih vapnenaca. Četiri ugljenonosna bazena, Karojba, Sveti Martin, Pićan i Labin, sadržavaju sedam rudnika, Tupljak, Potpićan, Kozljak, Strmac, Rašu, Ripendu i Krapan. Tamošnji ugljeni općenito su poznati pod nazivom raški ugljen. Taj ugljen izniman je u svjetskim razmjerima zbog visokoga sadržaja organskoga sumpora, koji može iznositi i do 14 \%. Stoga ovaj rad donosi pregled hrvatskih znanstvenih publikacija posvećenih različitim aspektima raškoga ugljena, zajedno $\mathrm{s}$ najvažnijim publikacijama bilo o ugljenu ili relevantnim temama diljem svijeta. Kratak uvod bavi se ulogom ugljena u proizvodnji električne energije te poviješću rudnika ugljena u Istri. Sljedeća poglavlja sažeto prikazuju postojeće znanje o geokemiji sumpora u ugljenu, s nekoliko primjera indijskih i kineskih ugljena s visokim sadržajem sumpora. Potom slijedi geološka, geokemijska i fizička karakterizacija raškoga ugljena. Na kraju su prikazani radovi koji se bave utjecajem izgaranja raškoga ugljena na okoliš s obzirom na to da su poremećaji ekosustava izazvani izgaranjem ugljena dokazani u brojnim radovima.

\section{Ključne riječi}

ugljen, rudarenje, sumpor, Raša, Istra 